\title{
Institutional Stickiness and the New Development Economics
}

\author{
By Peter J. Boettke, Christopher J. Coyne, \\ and PETER T. LEESON*
}

\begin{abstract}
Research examining the importance of path dependence and culture for institutions and development tells us that "history matters," but not how history matters. To provide this missing "how," we provide a framework for understanding institutional "stickiness" based on the regression theorem. The regression theorem maintains that the stickiness, and therefore likely success, of any proposed institutional change is a function of that institution's status in relationship to indigenous agents in the previous time period. This framework for analyzing institutional stickiness creates the core of what we call the New Development Economics. Historical cases of postwar reconstruction and transition efforts provide evidence for our claim.
\end{abstract}

Teeth-gritting humility, patience, curiosity and independent thinking are called for in learning how superior foreign technology works and how it can be improved. Without these conditions the technical assistance "does not take." The cut flowers wither and die because they have no roots.

Paul Streeten (1995: 11-12)

\section{Introduction}

FirST INTRODUCED BY NORTH (1990), the notion of institutional "path dependence" has received increasing attention among those interested in the connection between institutions and economic growth (see, for

*Peter J. Boettke is at the Department of Economics, George Mason University. Christopher J. Coyne is at the Department of Economics, West Virginia University. Peter T. Leeson is at the Department of Economics, George Mason University. We thank the Editor and an anonymous referee for helpful comments and suggestions. The financial support of the Earhart Foundation, the Oloffson Weaver Fellowship, the Mercatus Center, and the Kendrick Fund is also gratefully acknowledged.

American Journal of Economics and Sociology, Vol. 67, No. 2 (April, 2008).

(c) 2008 American Journal of Economics and Sociology, Inc. 
instance, Pierson 2000a, 2000b; Buchanan and Yoon 1994). Path dependence emphasizes the increasing returns to institutions, which tend to "lock in" particular institutional arrangements that have emerged in various places for unique historical reasons.

Locked-in institutional arrangements may be suboptimal in the sense that, given today's information, agents would be better off if they moved to some other arrangement. In such cases, it is typically argued that in order to put agents on a new and improved institutional path, some outside entity, like the development community, is required to provide the exogenous "shock" necessary to break society out of the suboptimal scenario. This belief has presently led development economists to emphasize the role of exogenous institutions in determining economic growth. Current analyses of economic development thus concern themselves with finding the "right" institutional mix to promote progress in various countries.

However, the success of these efforts has been spotty at best. For instance, most underdeveloped countries in sub-Saharan Africa and many postsocialist transitioning nations continue to struggle despite development-community attempts to exogenously introduce institutional change. We argue that this failure stems at least partly from the fact that the concept of path dependence as it has been applied to institutions to date tells us only that "history matters" in the development of institutions. It does not, however, tell us how history matters. Research that considers culture suffers from a similar problem. While this work performs an important function in pointing out that "culture matters," it does virtually nothing in terms of telling us analytically or empirically how culture matters (see, for instance, Buchanan 1992; Pejovich 2003; Boettke 2001b).

We aim to provide the missing "how" in these closely related streams of research. We contend that institutional "stickiness"-the ability or inability of new institutional arrangements to take hold where they are transplanted-is central to understanding how history matters for institutions. Furthermore, it is central to understanding how the relationship between history and institutions matters for development economics.

We provide a framework for understanding stickiness based on the regression theorem. ${ }^{1}$ The regression theorem maintains that the 
stickiness, and therefore likely success, of any proposed institutional change is a function of that institution's status in relationship to indigenous agents in the previous time period. This framework for analyzing institutional stickiness is at the core of what call the New Development Economics.

The New Development Economics builds directly on the voluminous body of research that examines the emergence, operation, and effectiveness of spontaneously ordered institutional arrangements. The idea that these institutions tend to be efficient and most effective in promoting the ends of indigenous agents is not original to us. On the contrary, Hayek $(1960,1973,1991)$ was among the first to emphasize these aspects of spontaneously emergent institutions, in particular law. Following him, a number of others including Glaeser and Shleifer (2002), La Porta et al. (1998), Djankov et al. (2003), Posner (1973), and Benson (1989) have examined the comparative properties of endogenously emergent common law systems versus exogenously created civil law systems, and in several cases their relationship to economic development, and have empirically confirmed Hayek's insights. Others, such as Nenova and Harford (2004), Hay and Shleifer (1998), and Leeson (2006, 2007a, 2007b), have pointed to the effectiveness of spontaneously emergent institutions for the provision of "public goods," including property rights protection, normally thought of as being capably provided only by the state. Still others have noted the effectiveness of monetary institutions when they emerge as spontaneous orders, and contrasted this with the relative ineffectiveness of such institutions when they are created in a "top-down" fashion by government (see, for instance, Menger [1871] 1994; Selgin 1994; Selgin and White 1994). Important work by Elinor Ostrom (1990, 2000) and James Scott (1998) also has highlighted the importance and success of endogenously emergent institutional solutions to a range of coordination problems, as well as the potential for unintended, undesirable outcomes when political authorities artificially construct institutional solutions to these problems.

These important strands of research have tended to contrast two kinds of opposing institutional emergence: those that emerge entirely spontaneously (what in our framework we call "indigenously introduced endogenous institutions"), and those that are constructed and 
imposed by "outsiders" (what in our framework we call "foreignintroduced exogenous institutions"). In addition to these opposing ends of the institutional spectrum, this article introduces a third class of institutions - those that are indigenously introduced but exogenous in nature. In introducing this third class of institutions and considering its "stickiness" properties alongside those institutions that fall on either side of it, we hope to illuminate what characteristics give institutions their stickiness and, in doing so, to provide a framework for investigating proposed institutional reforms in the context of economic development.

Finally, this article should also be seen as building on existing work in comparative institutional analysis. In addition to North (1990, 2005), Aoki (2001) emphasizes the importance of informal complementary institutions that allow formal institutions to function in the desired manner. Similarly, Platteau (2000) notes the importance of norms and complementary institutions for the operation of formal institutions such as the legal system.

The remainder of this article is organized as follows. Section II provides an institutional taxonomy for the purposes of analyzing the stickiness properties of various types of institutional arrangements. Section III presents the regression theorem and uses it to analyze the stickiness properties of institutional types. Based on this insight, this section also explores what our analytical findings suggest for the development community. In Section IV, we examine our framework in light of cases of postwar reconstruction and transition efforts in former Communist countries. To illuminate the regression theorem and its implications for economic development, we consider successful reconstruction in Germany and Japan and unsuccessful reform in Bosnia. We then consider cases of successful (Poland) and failed (Russia) transition efforts. In Section V, we conclude.

\section{A Taxonomy of Institutions}

WE CAN BROADLY CONCEIVE of institutions as belonging to one of three separate categories: foreign-introduced exogenous (FEX) institutions, indigenously introduced exogenous (IEX) institutions, and 
indigenously introduced endogenous (IEN) institutions. The foreign or indigenous component in each of these categories is fairly selfexplanatory: institutions designed chiefly by outsiders are foreignintroduced, while those designed chiefly by insiders are indigenously introduced. Of course, this breakdown significantly oversimplifies institutional origin. Nearly any institutional arrangement can be found to exhibit influence from outsiders at some point in time. Thus, institutions are never purely foreign or indigenously introduced. Nevertheless, we can broadly view institutions as being primarily the creation of foreign or indigenous forces in most instances, and it is in this spirit that we propose the distinction.

The exogenous/endogenous component of institutional origin requires additional explanation. Exogenous institutions are constructed and imposed from above. These are the creations of governments or other formal authorities like the IMF, USAID, or the World Bank. Note that these can be created indigenously by national governments or by outsiders when they are foreign-introduced. In contrast, endogenous institutions emerge spontaneously as the result of individuals' actions, but are not formally designed. Thus, by their nature, endogenous institutions are indigenously introduced.

Concretely, FEX institutions are those we typically associate with development-community policy. For instance, a legal system change introduced by the development community in a reforming nation would constitute a FEX institution. Although the decision regarding such a change ultimately lies in the hands of the indigenous government, the policy change is chiefly the creation of outsiders, and the institutional change is constructed.

IEX institutions are those we associate with the internal policies created by national governments. For example, federalism in the United States is an IEX institution. Federalism represents a stateconstructed institution designed by Americans. Similarly, the British Parliament constitutes an IEX institution. It is a designed institution of British construction.

Finally, IEN institutions are those we associate primarily with spontaneous orders. These embody the local norms, customs, and practices that have evolved informally over time in specific places. Language, for instance, is an IEN institution. 
Of course, these institutional categories are purely conceptual. Furthermore, they are not rigid, as presented above. The same institutions may fall into different categories in different places; perhaps even more importantly, the same institution may fall into different categories at different times in the same place. Consider, for instance, the institution of money. Before the advent of central banking, money constituted an IEN institution in much of $19^{\text {th }}$-century Europe (Rothbard 1990; White 1995). However, in the $20^{\text {th }}$ century, money creation was monopolized by national governments in most places in the world. Thus, in the $20^{\text {th }}$ century, money in Europe would be classified as an IEX institution.

III

\section{The Regression Theorem: A Framework for Analyzing Institutional Stickiness}

IT IS WIDELY AGREED that the underlying institutional framework of an economy influences its ability to progress (see, for instance, Scully 1992; Kasper and Streit 1999; North 1990; Platteau 2000). More specifically, there is a broad consensus within the development community that the market institutions of private property, rule of law, and liberal tradeso-called growth-inducing institutions-are required for successful development. ${ }^{2}$ However, while generally identifying growth-enhancing institutions is an important step in creating prosperity, questions remain about how to operationalize these answers to economic growth.

In this regard, perhaps the most important question we must consider is: Are these institutions transportable? Mixed empirical evidence heightens the significance of this question. On the one hand, recent attempts at imposing these institutions in developing nations abroad have met mostly with failure (Easterly 2001, 2006). On the other hand, not all institutional impositions have failed (Coyne 2007). For instance, for reasons explored in Section IV, postwar economic reconstruction in Japan and Germany proved relatively successful.

When we are talking about transporting institutions, we are necessarily talking about FEX institutions. Whether we are dealing with the introduction of development-community-devised policy in postsocialist transition nations or the imposition of new 
politico-economic orders in war-torn Europe, we are dealing with FEX institutions. The question thus emerges: What are the stickiness properties of FEX institutions, and how are they related to the stickiness properties of IEX and IEN institutions?

\section{A. Indigenously Introduced Endogenous (IEN) Institutions}

To answer this question, we begin by analyzing the properties of IEN institutions. This serves as an appropriate starting point for our analysis because, as we discuss below, IEN institutions necessarily precede effective FEX and IEX institutions historically. As spontaneous orders, IEN institutions have their roots in the behavior of individual agents pursuing their own ends (see, for instance, Menger [1871] 1994; Hayek 1996). To the extent that agents' ends are at least partially dependent upon social interaction, various obstacles to this pursuit emerge along the way. For instance, agents desiring exchange who lack a coincidence of wants find this problematic for executing desired transactions.

IEN institutions can be thought of as endogenously emergent solutions to such obstacles confronting socially interacting agents (Hayek 1996). For instance, in the example above, agents find recourse to resort to indirect exchange to overcome the lack of coincidence of wants in a barter economy. At first the medium of exchange employed between two traders for this purpose is a peculiarity. Only over time do agents find certain media of exchange more useful for facilitating exchange than other media, and only over time do more and more traders find it useful to resort to indirect exchange. At some point, particular media of exchange desired for their properties in enabling trade become so widespread that they take on the status of an institution. This is the spontaneous evolution of money (see, for instance, Menger [1871] 1994; Mises 1949; Selgin and White 1994).

Several things are worth noting about the process by which IEN institutions, like money, surface. First, they emerge endogenously. The institution is not constructed by some entity like government, exogenous to the market process. Second, the institution's endogenous emergence is necessarily indigenously introduced. As we have noted, precisely for these two reasons, we call these institutions IEN institutions. 
The features that make an institution an IEN institution are of particular importance in analyzing its stickiness properties. First, the endogenous emergence of the institution points to its desirability as seen from indigenous inhabitants' point of view. IEN institutions are informal in the sense that they are not compelled and are flexible to the changing preferences of the individuals they assist. As such, their persistence tends to indicate their preferredness to other informal arrangements that might supplant them (Hayek 1991).

Second, both features of IEN institutions suggest that these institutions are firmly grounded in the practices, customs, values, and beliefs of indigenous people. In other words, both the indigenous introduction of an IEN institution as well as its endogenous emergence strongly suggest an IEN institution's foundation in mètis.

A concept passed down from the ancient Greeks, mètis is characterized by local knowledge resulting from practical experience. ${ }^{3}$ It includes skills, culture, norms, and conventions, which are shaped by the experiences of the individual. This concept applies to both interactions between people (e.g., interpreting the gestures and actions of others) and the physical environment (e.g., learning to ride a bike). The components of mètis cannot be written down neatly as a systematic set of instructions. Instead, knowledge regarding mêtis is gained only through experience and practice.

In terms of a concrete example, think of métis as the set of informal practices and expectations that allow ethnic groups to construct successful trade networks. For instance, the diamond trade in New York City is dominated by orthodox Jews who use a set of signals, cues, and bonding mechanisms to lower the transaction costs of trading. The diamond trade would not function as smoothly if random traders were placed in the same setting. This difference can be ascribed to mêtis. Because it is based in the accepted, understood, and habituated mentalities and practices of indigenous peoples, the presence or absence of mêtis explains the stickiness of various types of institutions. In fact, mêtis can be thought of as the glue that gives institutions their stickiness.

IEN institutions ensure their foundation in mêtis for two reasons. First, the fact that they emerge endogenously in an informal, unconstructed fashion means that they emerge directly from mètis. Similarly, 
their indigenous introduction means that they are in harmony with local conditions, attitudes, and practices. This fact is closely related to Frey's (1997) important work on the "intrinsic motivations" of individuals, which suggests that spontaneously emergent institutions effectively reflect-and in fact grow out of - the preferences of local actors. In this sense, IEN institutions are institutionalized mētis. As such, IEN institutions tend to be the stickiest institutions of all.

Stephen Innes's (1995) study of the economic culture of Puritan New England provides an excellent example of the stickiness of IEN institutions based on their strong foundation in métis. According to Innes, the social ecology of Puritanism led to the success of the Massachusetts Bay Colony in the $17^{\text {th }}$ century. A mutated cultural mix of British culture with Puritan ideology among the settlers combined to free the economy of restraints and place moral sanction on private property and the work ethic.

The settlers' fierce devotion to God in this case led to a social commitment to engage the world and to prosper. This underlying customary belief system that composed part of Puritanical mètis was reinforced by market-based IEN institutions within the Puritan commonwealth, which promoted economic growth and development. Much of America's modern private property order is based upon Puritanical metis. Indeed, precisely because of this foundation in mettis, the institution of private property in the United States is extremely sticky, as evidenced by its persistence over centuries.

Private international commercial law provides another example of a highly sticky IEN institution rooted in mêtis. This law constitutes an outgrowth of the lex mercatoria, an informal system of customary law rooted in international commercial norms that evolved spontaneously from the desires of individuals to engage in cross-culture exchange in $11^{\text {th }}$ - and $12^{\text {th }}$-century Europe (Benson 1989; Leeson 2006). The contractual arrangements and procedures for dispute settlement that emerged endogenously as flexible solutions to obstacles confronting international traders under the lex mercatoria strongly reflected the evolved practices, norms, and customs of the traders, rooting these IEN institutions of international exchange in mêtis. These institutions have exhibited tremendous stickiness and, while continually evolving, remain the institutions that govern most international commerce in the 
modern world (see, for instance, Benson 1989; Berman 1983; Volckart and Mangles 1999).

\section{B. Indigenously Introduced Exogenous (IEX) Institutions}

We have seen how mettis acts as the glue that gives institutions their stickiness. Furthermore, we have seen why IEN institutions, with their close relationship to mêtis, tend to be the stickiest institutions. But what about FEX and IEX institutions? Where do they fall in terms of stickiness?

As our analysis suggests, the further an institution falls from mêtis, the less sticky it will be. IEX institutions are indigenous, but are exogenously introduced. This means that while some formal authority is responsible for creating the institution, this formal authority is not foreign. Because IEX institutions are exogenously imposed, the tendency for them to be as closely connected to mêtis as IEN institutions is missing. The fact that formal authorities lack intimate knowledge of mêtis creates a greater likelihood for incongruities between the imposed institution and the underlying mêtis.

Consider, for example, J. Stephen Lansing's (1991) study of the Balinese water temples. The water temples scattered across Bali were places of worship of various gods, but they also managed the irrigation schedule for farmers throughout Bali. In the 1960s and 1970s, the International Rice Research Institute sought to eradicate the backward native practices of rice production throughout Asia. This was known as the "Green Revolution."

Indigenous methods of rice production would be replaced with a variety of rice that required the use of fertilizers and pesticides. In Bali, the government introduced an agricultural policy in conformity with the Green Revolution, which promoted continuous cropping of the new rice. Rice farmers were encouraged to plant rice without taking account of the traditional irrigation schedule dictated by the water temples. The immediate effect was a boost in rice production, but the policy soon resulted in a water shortage and a severe outbreak of rice pests and diseases. In short, the IEX institution created by the Balinese not only failed to have its desired effect but actually made matters worse. In this way, because IEX institutions are 
exogenously imposed, they often fail to conform to underlying mētis.

However, given that the authority creating an IEX institution is familiar to some degree with local practices, attitudes, and so forththat is, it may itself be part of a larger local métis - it stands to reason that the authority is able to craft institutions in such a way as to be relatively consistent with these factors. In this way, some relationship between IEX institutions and mētis remains intact. The dual components of IEX institutions thus pull them in two opposing directions relative to mêtis. On the one hand, the fact that they are indigenously introduced pulls them closer to mettis. On the other hand, the fact that they are created by formal authorities who tend to be somewhat remote from actors pulls them away from mêtis. So, while less sticky than IEN institutions, IEX institutions retain some stickiness.

As we note above, many formerly IEN institutions, such as law and money, have become IEX institutions as governments have grown and taken control over them. Precisely because these IEX institutions have their roots in IEN institutions closely connected to métis, they have proved quite sticky despite their changed institutional status. Much of the American legal code, for instance, essentially codifies preexisting informal common law arrangements. Similarly, with money, the U.S. dollar is historically connected to the thaler (pronounced "tholler") — a unit of silver currency from the days of privately minted commodity money in $15^{\text {th }}$-century Europe (Rothbard 1990). These examples illustrate successful IEX institutional impositions.

As the Balinese example points out, however, these successes do not mean that all IEX institutions are always sufficiently sticky. Their relative lack of stickiness compared to IEN institutions does place some parameters on what successful IEX institutions can look like. For instance, if the U.S. government decided that ashtrays would circulate tomorrow as the new legally mandated medium of exchange, this institutional change would not stick. People would simply refuse to use ashtrays for this purpose or would resort to a black market in currency, where dollars or gold would circulate as the de facto medium of exchange. The notion of ashtrays as money strongly conflicts with American mêtis. As such, the glue needed to make this new institution stick would be absent. In this way, the necessity of 
having some IEN institution to act as a mêtis-based core for IEX institutions constrains what IEX institutions are possible.

When it comes to IEX institutions, there are again two countervailing forces at work. Local authorities have better knowledge than foreign authorities about existing focal points that serve to coordinate the local population's activities. Pulling in the other direction, however, is the fact that institutional change in this case occurs exogenously, and so may not fully respect existing nodes of orientation.

\section{Foreign-Introduced Exogenous (FEX) Institutions}

Following our logic, FEX institutions tend to be the least sticky of all. On the one hand, unlike IEN and IEX institutions, FEX institutions are foreign-introduced. This means that the distance between the process of institutional design and the location of hoped institutional "takehold" is considerable. Foreign institutional designers are less equipped to tailor institutions in such a way that they do not conflict with indigenous mêtis because of this increased physical and social distance, which tends to make designers less aware of the local conditions where they desire to transplant institutions. Compounding this increased distance, FEX institutions are exogenous. So, like IEX institutions, they are less connected to mêtis because formal authorities that tend to be more remote from parochial environments create them.

Both of these features tend to make FEX institutions lack the stickiness for them to be effective. Consider, for instance, Robert Blewett's (1995) study of the pastoral policy of the Maasai in Kenya. Precolonization, the Maasai followed a practice of communal ownership governed by tacit norms of restricted access. This practice evolved as a method to reduce the transaction costs associated with the collective action necessary for cooperation, including pastoral coordination and environmental risk management.

British colonial rule, however, substituted explicit contracts for the tacit norms governing land usage in practice. Explicit contracts did not codify an existing IEX or IEN institution, but instead were created in direct conflict with existing underlying mêtis about land usage. As a result, the complex IEN institutional land structure of the Maasai was 
disrupted, and the long-term viability of the common land was destroyed. According to Blewett, this destruction undermined the existing Maasai social structure that enabled cooperative agriculture and created a situation of rampant conflict among formerly cooperative agents that manifested itself in the form of rent-seeking activities. ${ }^{4}$

Since, concretely, FEX institutions are those created by the development community for transplant in reforming countries, their tendency to lack stickiness is a severe problem indeed. This suggests that even if the development community can correctly identify what institutions are required for growth in general terms, it cannot transplant these institutions where they do not exist as a means of promoting development. Attempts to do so are unlikely to work because host countries reject FEX institutions, which lack the glue required to stick.

This is certainly not to say that host countries always reject FEX institutions. FEX institutions can, and have in some cases, successfully taken hold where they are transplanted. As we discuss below, Japan and Germany's post-World War II reconstruction provide a case in point. However, the relative lack of FEX institution stickiness places significant constraints on what successful FEX institutions can look like.

In the same way that successful IEX institutions are connected to IEN institutions, successful FEX institutions are connected to IEX institutions. In other words, because FEX institutions that embody formerly IEX institutions are closer to mêtis, they are more likely to stick than FEX institutions that do not embody formerly IEX institutions. For instance, while attempts at imposing private property orders among stateless tribes in sub-Saharan Africa are unlikely to work, creating constitutional provisions in post-World War II Germany that embody some elements of pre-Nazi Germany's constitution have a greater chance of working. Likewise, the use of preexisting institutions by occupiers in the post-World War II reconstruction of Japan was a major reason for the stickiness of FEX institutions.

In short, the connection to mêtis weakens as we move from IEN to FEX institutions. Thus, stickiness falls as we move in this direction as well. Figure 1 illustrates this relationship graphically.

Because successful IEX institutions form the basis for effective FEX institutions and successful IEX institutions must embody IEN 
Figure 1

\section{Institutional Stickiness}

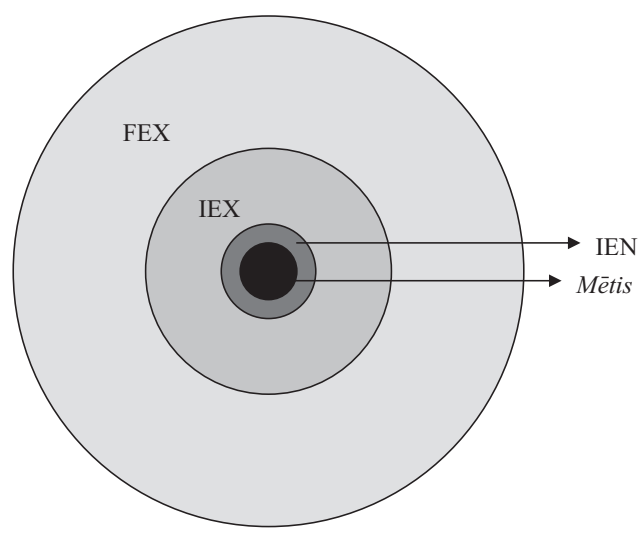

institutions, indirectly, IEN institutions constrain the form of FEX institutions as well. In circumscribing what shape FEX and IEX institutions may take, IEN institutions point to an important result for development economics. Successful institutional changes in developing parts of the world must have IEN institutions at their core. ${ }^{5}$ We place this claim at the center of the New Development Economics. To determine if any particular development-community proposal for institutional change meets this criterion, we suggest the following test: If the proposed change cannot be traced back to an IEN institution, it should not be attempted.

We call the claim that successful institutional changes must be ultimately traceable to IEN institutions the regression theorem. The regression theorem states that the stickiness, $S$, of any given institution, $I$, in time $t$ is a function of that institution's stickiness in time $t-1$. The stickiness of this institution in $t-1$ is in turn a function of its stickiness in $t-2$, and so on. In other words, $S_{t}^{I}=S_{t}^{I}\left(S_{t-1}^{I}\right)$, where $S_{t-1}^{I}=S_{t-1}^{I}\left(S_{t-2}^{I}\right)$, and, generally, $S_{t-n}^{I}=S_{t-n}^{I}\left(S_{t-(n+1)}^{I}\right)$.

This chain, however, does not infinitely regress. This is because the stickiness of an institution at the time of its emergence an arbitrarily 
large number of periods ago, $N$, is determined by its status vis-à-vis agents when it first emerges as an institution in $t-N$. That is, in $t-N$, the stickiness of institution $I$ depends upon whether it is an IEN, IEX, or FEX institution. So, $S_{t-N}^{I}=S_{t-N}^{I}\left(I^{\mathrm{IEN}}, I^{\mathrm{IEX}}, I^{\mathrm{FEX}}\right)$ where $S^{I^{\mathrm{IEN}}}>S^{I^{\mathrm{IEX}}}>S^{I^{\mathrm{FEX}}}$ per our analysis from above. In this way, the regression theorem grounds the stickiness of institutions today in their past stickiness, which is ultimately a function of how closely they are connected to mètis.

It is important to note that in our framework, institutional stickiness is not equivalent to institutional "goodness." Although Hayek (1960, 1991) and others have highlighted a tendency for efficient institutions to evolve when they do so endogenously, it is not the case that every endogenously created institution in all circumstances is efficient or conducive to economic development. Thus, that a particular institution is traceable back to an IEN institution does not itself establish that it is conducive to economic growth. In fact, many IEN institutions are themselves growth inhibitors. For instance, if the embedded local custom in Tanzania has a taboo on private ownership, Tanzania will have difficulty progressing. The regression theorem only points out that if the institution of private property is imposed on Tanzania, it will have trouble sticking and will probably not produce the desired effect. In this sense, we should understand the traceability of a proposed institutional change to an IEN institution under the regression theorem as providing insight regarding the limitations of development-community activity, rather than as establishing evidence of having met the institutional requirements that progress demands.

It is equally important to point out that not all FEX institutions that exhibit sufficient stickiness to take hold where they are imposed promote growth. For instance, in many parts of Stalinist Eastern Europe, FEX institutions imposed by force stuck, but harmed economic progress. The fact that a particular FEX institution sticks speaks only to the fact that an IEX institution (and indirectly IEN institution rooted in mêtis) is at its core. The core IEX or IEN institution it is built around may be "bad" in the sense that it is an obstacle to development. Stickiness is therefore a necessary though not sufficient institutional attribute for creating economic growth. 
IV

\section{Historical Examples}

HistoricAlLY, We FIND empirical support for the framework outlined above. We first focus on cases of postwar reconstruction in which new political and economic orders are imposed upon a populace. We look at what are considered relatively successful reconstructions-postWorld War II Japan and West Germany. Next, we look briefly at Bosnia as a case in which reconstruction efforts have been unsuccessful due to the failure of FEX institutions to dovetail with mêtis. We then turn to cases of transition economies, where we consider successful (Poland) and failed (Russia) transition efforts within the framework developed above.

\section{A. Successful Reconstruction in Japan and West Germany: Dovetailing Mētis with FEX Institutions}

Japan and West Germany are usually considered instances of successful reconstruction, meaning the development of a self-sustaining democracy. In both cases, there was an occupation by external military forces and a democratic political order was imposed in a short period of time.

Americans-notably General Douglas MacArthur, the Supreme Commander of the Allied Powers for the Occupation and Control of Japan (SCAP)—played a key role in rebuilding Japan. MacArthur produced an English-language draft of the new Japanese constitution in 10 days. After eight months of negotiations in which minor changes were made, Japanese politicians presented the constitution, in Japanese, to the populace as their own innovation. Following the reconstruction period (1945 through the early 1950s), Japan experienced a period of high growth, lasting through about 1990.

We can attribute the success of Japan's reconstruction to the fact that a significant portion of the Japanese mettis remained intact in the postwar period. For centuries, Japanese culture has been geared toward large-scale organizations and a positive view of trade and market exchange (Fukuyama 1996: 161-170). Such a culture aligns well with the incentives of a liberal political and economic structure. 
In the reconstruction process, while mettis indeed changed, the key aspects of the commercial heritage remained intact. The practical knowledge that allowed people to coordinate in the prewar period allowed for similar results in the postwar period.

Moreover, the translation of the imposed constitution from English to Japanese shows the potential value of ambiguity. While the native Japanese did not play a large role in drafting the new constitution, they did play a role in translating it into Japanese. The English and the Japanese versions differ because in many cases the two languages do not have equivalent terminology (Inoue 1991). While the Japanese adopted a constitution affirming their commitment to Western democratic institutions, much of the language expresses pre-World War II traditional Japanese social and political values. In other words, the FEX institutions created under the constitution retained key elements of traditional Japanese mêtis and in this sense embodied preexisting IEX and IEN institutional arrangements. Finally, U.S. occupiers relied on existing IEX and IEN institutions, such as the emperor and the Diet, to implement policy changes. The use of these established and accepted solutions facilitated the acceptance of FEX institutions.

The fact that mettis remained intact played an important role in postwar Germany as well. Given that German governments at the local level had a strong tradition of self-government, a 1944 U.S. Civil Affairs Guide indicated that local politics was to be the springboard for political reform throughout Germany (Boehling 1996: 156). Writing on British plans to democratize Germany, Marshall notes: "It was recognized, however, that beneath the nationalist and aggressive policies perpetuated by German central governments, there had existed a healthy democratic tradition at the local level" (1989: 191).

Allied advisors, many of whom who were experts in German history, recommended retaining particular indigenous traditions. The reconstruction process, for instance, included some native Germans. The military governments in the U.S. zone appointed Germans in villages, towns, and cities to assist in the implementation of Allied policies. In choosing native Germans for these positions, emphasis was placed on past administrative experience and the perceived ability to cooperate with military authority rather than on prodemocracy/anti-Nazi leanings (Boehling 1996: 271). As a result, at 
least part of the German mêtis was incorporated into the political rebuilding process, which in turn supported the stickiness of FEX institutions in the reconstructed political order.

In sum, while there was widespread physical destruction in both Japan and Germany, the preexisting endowment of mêtis remained largely intact. As Eva Bellin notes, despite the physical damage, "Japan and Germany retained the human, organizational, and social capital (that is, skilled workers, skilled managers, and social networks)" (2004-2005: 596). The endowment of mettis included the complementary institutions required to allow externally reconstructed formal institutions to sustain and operate in the desired manner.

\section{B. Unsuccessful Reconstruction in Bosnia: Conflict Between Mētis and FEX Institutions}

Bosnia is a case in which postwar reconstruction has failed to develop self-sustaining institutions that facilitate economic development. The three and a half years of internal ethnic conflict in Bosnia ended with the signing of the Dayton Peace Agreement (DPA) in 1995 and then the arrival of international peacekeepers. It is critical to note that while there was no occupying force present to "impose" order in Bosnia, the DPA was reached "only after the United States and other key participants exerted substantial pressure on the ... parties" (Kreimer et al. 2000: 23). In other words, the DPA did not arise through indigenous desires to achieve peace, but from outside pressures coupled with the presence of peacekeepers.

Despite obtaining some semblance of peace, the DPA has failed to put Bosnia on a path of sustainable development. Indeed, it is far from clear that a sustainable order would exist if troops and peacekeepers were to withdraw. The fact that the FEX institutional-based peace treaty was not aligned with the underlying mettis of the parties involved, coupled with the stipulations of the DPA regarding the political order, is to blame for the reconstruction's failure.

The DPA implemented a single state, but it also created a multilayered political structure consisting of multiple entities with often conflicting interests. For instance, the two entities created by the DPA, the Federation of Bosnia and Herzegovina and Republika Srpska, 
share some common institutions in the form of a General Council of Ministers. Further, the tripartite presidency consists of one Bosnian, one Bosnian Croat, and one Bosnian Serb, who rotate power every eight months. These common FEX political institutions oversee a range of policy issues including foreign relations, monetary and fiscal policy, and other social policies and regulations.

However, it is important to note that the existence of additional sovereign institutions below these common FEX institutions has created an ongoing conflict of interests. For instance, each entity has a separate constitution, president, vice-president, and political system. Further, the Office of High Representative (OHR) has overriding authority implementing the peace process. The composition of the OHR, a FEX institution, is nominated by the Peace Implementation Council, which consists of 55 countries and organizations involved in the peace process, approved by the U.N. Security Council. The complicated structure of the Bosnian government along with the outside influence of the OHR creates a clash between the newly created FEX institutions and underlying mettis. The very structure of the government allows for a continued conflict of interests at virtually all levels. The existence of multiple constitutions has allowed different entities to pursue different and often conflicting ends.

The reconstruction of Bosnia illustrates another problem: the FEX democratic process was rushed before the political order aligned with underlying mêtis. The timing of elections was set at the signing of the DPA and stated that elections should take place no later than nine months after the signing. The rushed elections prevented the development of grassroots support for democracy, and existing nationalist parties thus had a distinct advantage.

It may be argued that the reason efforts in Bosnia and elsewhere (such as Haiti, Afghanistan, and Kosovo) have failed is because of a lack of international aid and manpower. However, a consideration of international funding and military presence across reconstruction efforts demonstrates that this is not the case. If one looks at the per capita assistance during the first two years after the end of conflict, it is clear that relatively high levels of external assistance do not guarantee success. Bosnia received approximately $\$ 1,400$ per person, while Kosovo received slightly over $\$ 800$ per resident, Germany 
approximately \$300, Haiti approximately \$200, and Japan and Afghanistan approximately $\$ 100$ per resident (Dobbins et al. 2003: 158). ${ }^{6}$ Bosnia, Kosovo, Haiti, and Afghanistan must all be considered unsuccessful if our benchmark is a self-sustaining democracy.

Likewise, the number of soldiers per thousand inhabitants of each country at the conclusion of conflict does not guarantee success. ${ }^{7}$ Initial deployment was relatively high in Germany (approximately 100 soldiers per 1,000 inhabitants), Bosnia (18.6 soldiers per 1,000 inhabitants), and Kosovo (20 soldiers per 1,000 inhabitants). However, initial force levels were relatively low in Japan ( 5 soldiers per 1,000 inhabitants), Haiti (3.5 soldiers per 1,000 inhabitants), and Afghanistan (2 soldiers per 1,000 inhabitants) (Dobbins et al. 2003: 149-151). Again, we observe successes and failures in both the case of relatively high and low military presence. Clearly, aid and military presence cannot, by themselves, explain successful reconstruction. It is our contention that mettis is one of the key factors that allows for the achievement of such successes. If underlying mêtis does not dovetail with the institutions being imposed, these institutions will fail to stick regardless of the level of aid or military presence provided.

\section{The Transitions of Poland and Russia: Contrasting Cases of Mētis's Relationship to Institutional Reform}

As with reconstruction efforts, transition involves the shifting of institutions. Whether these institutions stick and have the desired effects depends upon the degree to which they dovetail with the mêtis of politicians and the populace. This fact is evident in the privatization efforts in both Poland and Russia. We must note upfront that both Poland's and Russia's transitions are vast topics and we do not pretend to cover all of their nuances or angles. Nonetheless, we seek to provide some basic insights in the context of the framework developed above.

Poland's transition must be considered a relative success compared to other countries in similar situations. From 1992 to 2000, its GDP grew at an average of 5 percent to 6 percent a year. Russia's economic performance in the transition period stands in clear and dramatic contrast to Poland's. In the aftermath of transition efforts, Russia's GDP fell by 40 percent from 1991 to 1998, with a 5 percent decline in 1998. 
Moreover, Poland has not been plagued by the extensive corruption, crony capitalism, or theft of state property that characterize Russia (Goldman 2003: 200). Both countries were communist and began undertaking reforms at the same time. Why do we observe this dramatic difference?

By looking closely at the pre- and postwar mêtis in both countries, it is clear that Poland had the underlying mêtis to support privatization efforts while Russia did not. Considering Poland first, its transition to the market was facilitated by the fact that a small but legitimate number of private firms had been tolerated throughout the communist reign. Although it is clear that these private firms were not a dominant part of Poland's economy during the communist period, they did serve to develop a métis of "how to get things done" in the context of private business interactions. Following the collapse of communism and the subsequent privatization efforts, it was easier for both the populace and politicians to build on that underlying mettis and accept private business on a much grander scale.

Even before the collapse of communism, Poland passed the 1988 Law on Economic Activity, which granted every Polish citizen the right to engage in private business. During 1990-1995, about 2 million new businesses were registered, with an additional 1 million registered over the next five years (Goldman 2003: 200-201). A survey of the richest 100 businessmen in Poland concluded that most Polish citizens built their fortunes via startups. As we will see below, this stands in stark contrast to Russia, where most of the oligarchs became wealthy by taking over control of state assets. It must also be noted that close to 80 percent of the farms in Poland were not collectivized. While this does not mean that they operated efficiently, it does mean that they developed a unique mêtis based on private ownership that served to facilitate privatization efforts.

We have already noted Russia's poor economic performance in the postcommunist period. As with Poland, a brief consideration of the preand postcommunist mètis in Russia adds insight into Russia's failure. In 1992, those in charge of reform-Yegor Gaider and Anatoly Chubaisalong with economic and legal advisors from both the United States and Russia formulated a bold plan for privatization, and reformers moved immediately to privatize up to 70 percent of state enterprises. These 
privatization efforts failed, largely because after 70 years of communism the social, political, and economic climate was not ready for privatization (Goldman 2003: 76). In other words, the underlying mettis necessary to support the privatization efforts was lacking and had no roots in the pretransition period. The reformers recognized this but proceeded nonetheless. As Shleifer and Vishny (who were part of the reform team) wrote, "[t]he architects of Russian privatization were aware of the dangers of poor enforcement of property rights" but assumed they would come into existence after privatization (1998: 11). As a result, privatization efforts failed to stick as expected.

In Poland, even under communist rule, some private business was allowed. There was nothing, however, comparable in the Soviet Union. The pretransition mêtis that allowed for the smooth postcommunist shift to privatization that existed in Poland was missing in Russia. The result was widespread corruption, crony capitalism, and the prevalence of organized crime. Reform efforts failed to be effectively supported by both politicians and the populace- the mêtis that acts as the glue to give institutional changes their stickiness was absent.

It is also important to note that, like in the case of Bosnia, the inability of designed institutional changes to stick in Russia was not the result of insufficient aid. Between 1991 and 1999, Russia received over $\$ 90$ billion in assistance from the international community. In today's dollars, this sum is roughly equivalent to the $\$ 13.3$ billion provided by the United States between 1948 and 1951 to Europe for postwar reconstruction (Boettke 1999). While Russia's transition has been relatively unsuccessful, postwar reconstruction efforts proved largely effective. Foreign aid thus cannot explain institutional stickiness. Something else, which we identify as the degree of congruity between proposed institutional changes and existing mêtis, must be at work.

The cases of Poland and Russia offer key insights into why some transition countries have performed relatively better as compared to others. In the case of Poland, where the underlying pretransition mêtis dovetailed with reform efforts, the institutions stuck and were successful. In Russia, where an underlying mêtis supporting privatization did not exist, these reforms failed to have the desired impact.

As we have seen here, the only way such a regime can be effective is if enough politicians and the populace coordinate around and 
support the regime change. In other words, underlying mettis must exist to support such a system. Before concluding, we must reiterate that metis is not a static concept. It is possible for a new and unique mettis to develop over time. Therefore, it must be realized that it is at least possible for economies trapped in underdevelopment to eventually change paths. But until that new mêtis is in place, reformers must realize that efforts to impose institutions, whether from within or from without, are likely to fail.

$\mathrm{V}$

\section{Conclusion}

OUR ANALYSIS HAS significant implications for economic development. First, recognition of the importance of IEN institutions in creating sustainable development suggests that current programs aimed at affecting reform exogenously are unlikely to work. IEN institutions emerge endogenously as spontaneous orders to overcome obstacles that otherwise stand in the way of individuals' ability to interact for mutual gain. Institutions that are imposed exogenously do not have the social memory grounded in mêtis that gives IEN institutions their credibility and workability among local agents. In ignoring this fact, the development community overestimates its ability to promote growth and underestimates the role of internally driven change in creating prosperity.

Furthermore, by using stickiness to explain how history matters for institutional development, our analysis suggests an important corollary result for development economics. Though theoretically exogenous force is needed to jolt agents out of suboptimal institutional arrangements, such force has low voltage precisely because it is exogenous. In other words, despite the fact that exogenously introduced change provides a conceptual way out of locked-in, inferior institutional arrangements, realistically, its power to alter institutional paths is severely limited.

Our application of the regression theorem to institutions provides a means of analyzing ex ante the potential success or failure of various institutions that the development community is considering introducing in varying developing nations. As our examination of West 
Germany and Japan's post-World War II reconstruction histories illustrates, if the institution being considered is traceable back to an IEN institution (or an IEX institution that is itself traceable to an IEN institution), its chances of success are significantly increased. On the other hand, as the cases of Bosnia and Russia suggest, if this is not the case, institutional changes are unlikely to stick despite developmentcommunity efforts to the contrary. Thus, while it may be an overstatement to say that the only path to progress is an indigenous one, it does not seem an exaggeration to say that any path to progress with a reasonable probability of success must ultimately be rooted in indigenous institutional order.

This is an important insight given the post-September 11 focus of Western policy on spreading liberal democratic institutions to the Middle East. Timur Kuran (2004) has analyzed several evolutionary "bottlenecks" that have contributed to the persistence of economic underdevelopment in the Middle East region. These bottlenecks have prevented the indigenous development of the complementary institutions necessary for the operation of formal Western institutions. The framework developed here can contribute to understanding how these bottlenecks may prevent the ability of external actors to implement Western-style institutions in this region.

Finally, our framework offers a potentially fruitful avenue for future research. We have sketched the key features of the New Development Economics, which uses the insights of the regression theorem to emphasize the critical role that indigenous institutions and institutional stickiness play in promoting or inhibiting economic growth. In addition to using the regression theorem to evaluate current proposals for exogenous institutional reform in the developing world, an important first step in building the New Development Economics approach might examine historical cases in this light as a means of giving us a better idea about how indigenous and endogenously emergent institutions influence the process of reform.

\section{Notes}

1. The idea of the regression theorem comes from Mises ([1912] 1980), who created the concept to explain why grounding the purchasing power of 
money in marginal utility theory did not lead to an infinite regress, as some before him had maintained. See also Selgin (1994) on assuring the acceptance of fiat currency.

2. This is not meant to be an exhaustive list of the ingredients necessary for economic growth. It is simply intended to highlight that there is some agreement on the general, underlying institutions required for development. For example, there is significant empirical evidence that the socialist model of planned industrialization does not work (see Boettke 1990, 1993, 1994, 2001a, 2001b). Furthermore, there is evidence that market economies grounded in a rule of law that protects private property and freedom of contract demonstrate robust progress (see, for example, Gwartney and Lawson 2003; Gwartney, Lawson, and Block 1996; Gwartney, Holcombe, and Lawson 1998, 1999; Scully 1992; O'Driscoll et al. 2003).

3. The anthropologist James Scott (1998) has recently attempted to revive the concept of mettis.

4. For more on how colonial-created institutions inconsistent with indigenous, informal institutions created havoc in Africa, see Leeson (2005).

5. As noted above, our argument here is closely related to Frey (1997), who emphasizes the need to build institutions that respect the intrinsic motivations of agents.

6. Assistance per capita is in 2001 U.S. dollars.

7. The figure for Germany represents the level of U.S. troops at the end of the war as a proportion of the population in the U.S. sector. Note also that the troop presence was the highest in each case at the conclusion of conflict and declined thereafter.

\section{References}

Aoki, Masahiko. (2001). Toward a Comparative Institutional Analysis. Cambridge: MIT Press.

Bellin, Eva. (2004-2005). "The Iraqi Intervention and Democracy in Comparative Historical Perspective." Political Science Quarterly 119(4): 595-608.

Benson, Bruce. (1989). "The Spontaneous Evolution of Commercial Law." Southern Economic Journal 55(3): 644-661.

Berger, Peter L. (1996). The Capitalist Revolution. New York: Basic Books.

Berman, Harold. (1983). Law and Revolution: The Formation of the Western Legal Tradition. Cambridge: Harvard University Press.

Blewett, Robert A. (1995). "Property Rights as a Cause of the Tragedy of the Commons: Institutional Change and the Pastoral Maasai of Kenya." Eastern Economic Journal 21(4): 477-490.

Boehling, Rebecca. (1996). A Question of Priorities: Democratic Reform and Economic Recovery in Postwar Germany. Providence, RI: Berghahn Books.

Boettke, Peter J. (1990). The Political Economy of Soviet Socialism: The Formative Years, 1918-1928. Boston: Kluwer Academic Publishers. 
(1993). Why Perestroika Failed: The Politics and Economics of Socialist Transformation. New York: Routledge.

(Ed.). (1994). The Collapse of Developmental Planning. New York: New York University Press.

. (1999). "The Russian Crisis: Perils and Prospects for Post-Soviet Transition." American Journal of Economics and Sociology 59(3): 371-384.

. (2001a). "The Political Infrastructure of Economics Development." In Calculation and Coordination: Essays on Socialism and Transitional Political Economy. New York: Routledge.

—. (2001b.) "Why Culture Matters: Economics, Politics and the Imprint of History." In Calculation and Coordination: Essays on Socialism and Transitional Political Economy. New York: Routledge.

Buchanan, James M. (1992). Post-Socialist Political Economy: Selected Essays. London: Edward Elgar Publishing.

Buchanan, James, and Yong Yoon. (1994). The Return of Increasing Returns. Ann Arbor: University of Michigan Press.

Coyne, Christopher. (2007). After War: The Political Economy of Postwar Reconstruction. Stanford: Stanford University Press.

Djankov, Simeon, Rafael La Porta, Lopez-de-Silanes Florencio, and Andrei Shleifer. (2003). "Courts." Quarterly Journal of Economics 118(2): 453517.

Dobbins, James, John G. McGinn, Keith Crane, G. Jones Seth, Rollie Lal, Andrew Rathmall, Rachel Swanger, and Anga Timilsina (Eds). (2003). America's Role in Nation-Building: From Germany to Iraq. Santa Monica, CA: RAND.

Easterly, William. (2001). The Elusive Quest for Growth: Economists' Adventures and Misadventures in the Tropics. Cambridge: MIT Press.

- (2006). The White Man's Burden: Why the West's Efforts to Aid the Rest Have Done So Much Ill and So Little Good. New York: Penguin Press.

Frey, Bruno S. (1997). Not Just for the Money: An Economic Theory of Personal Motivation. Cheltenham, UK: Edward Elgar Publishers.

Fukuyama, Francis. (1996). Trust. New York: Simon \& Schuster.

Glaeser, Edward, and Andrei Shleifer. (2002). "Legal Origins." Quarterly Journal of Economics 117(4): 1193-1229.

Goldman, Marshall I. (2003). The Privatization of Russia: Russian Reform Goes Awry. New York: Routledge.

Gwartney, James D., Randall Holcombe, and Robert Lawson. (1998). "The Scope of Government and the Wealth of Nations." Cato Journal 18: 163-190.

- (1999). "Economic Freedom and the Environment for Economic Growth." Journal of Institutional and Theoretical Economics 155: 643-663.

Gwartney, James D., and Robert Lawson. (2003). Economic Freedom of the World: 2003 Annual Report. Vancouver: Fraser Institute. 
Gwartney, James D., Robert Lawson, and Walter Block. (1996). Economic Freedom of the World: 1975-1995. Vancouver: Fraser Institute.

Hay, Jonathan, and Andrei Shleifer. (1998). "Private Enforcement of Public Laws: A Theory of Legal Reform." American Economic Review 88(2): 398-403.

Hayek, F. A. (1960). The Constitution of Liberty. Chicago: University of Chicago Press.

- (1973). Law, Legislation, and Liberty, vol. 1. Chicago: University of Chicago Press.

—. (1991). The Fatal Conceit. Chicago: University of Chicago Press.

- (1996). Individualism and Economic Order. Chicago: University of Chicago Press.

Innes, Stephen. (1995). Creating the Commonwealth: The Economic Culture of Puritan New England. New York: Norton.

Inoue, Kyoko. (1991). MacArthur's Japanese Constitution: A Linguistic and Cultural Study of Its Making. Chicago: University of Chicago Press.

Kasper, Wolfgang, and Manfred E. Streit. (1999). Institutional Economics: Social Order and Public Policy. London: Edward Elgar.

Kreimer, Alcira, Robert Muscat, Ann Elwan, and Margaret Arnold. (2000). Bosnia and Herzegovina: Post-Conflict Reconstruction. Washington, DC: World Bank.

Kuran, Timur. (2004). "Why the Middle East is Historically Underdeveloped: Historical Mechanisms of Institutional Stagnation." Journal of Economic Perspectives 18(3): 71-90.

Lansing, J. Stephen. (1991). Priests and Programmers: Technologies of Power in the Engineered Landscape of Bali. Princeton, NJ: Princeton University Press.

La Porta, Rafael, Lopez-de-Silanes Florencio, Andrei Shleifer, and Robert Vishny. (1998). "Law and Finance." Journal of Political Economy 106(6): 1113-1155.

Leeson, Peter T. (2005). "Endogenizing Fractionalization.” Journal of Institutional Economics 1(1): 75-98.

—. (2006). "Cooperation and Conflict: Evidence on Self-Enforcing Arrangements and Heterogeneous Groups." American Journal of Economics and Sociology, 65(4): 891-907.

—. (2007a). "Efficient Anarchy." Public Choice, 130(1-2): 41-53.

- (2007b). "Trading with Bandits." Journal of Law and Economics, 50(2): 303-321.

Marshall, Barbara. (1989). "British Democratisation Policy in Germany." In Reconstruction in Postwar Germany. Ed. Ian D. Turner. Oxford: Berg Publishers.

Menger, Carl. ([1871] 1994). Principles of Economics. Grove City, PA: Libertarian Press. 
Mises, Ludwig von. ([1912] 1980). The Theory of Money and Credit. Indianapolis, IN: Liberty Fund.

-. (1949). Human Action: A Treatise on Economics. New Haven: Yale University Press.

Nenova, Tatiana, and Tim Harford. (2004). "Anarchy and Invention." Public Policy for the Private Sector, Note No. 280. Washington, DC: World Bank.

North, Douglass C. (1990). Institutions, Institutional Change, and Economic Performance. Cambridge: Cambridge University Press.

- (2005). Understanding the Process of Economic Change. Princeton, NJ: Princeton University Press.

O'Driscoll, Gerald P., Edwin J. Feulner, and Mary Anastasia O'Grady. (2003). Index of Economic Freedom. New York: Heritage Foundation and Dow Jones \& Company.

Ostrom, Elinor. (2000). "Collective Action and the Evolution of Social Norms." Journal of Economic Perspectives 14(3): 137-158.

- (1990). Governing the Commons: The Evolution of Institutions for Collective Action. New York: Cambridge University Press.

Pejovich, Svetozar. (2003). "Understanding the Transaction Costs of Transition: It's the Culture, Stupid." Review of Austrian Economics 16(4): 347-361.

Pierson, Paul. (2000a). "The Limits of Design: Explaining Institutional Origins and Change." Governance 13(4): 475-499.

—. (2000b). "Returns, Path Dependence and the Study of Politics." American Political Science Review 94(2): 251-267.

Platteau, Jean-Philippe. (2000). Institutions, Social Norms, and Economic Development. Amsterdam: Harwood Academic Publishers.

Posner, Richard. (1973). The Economic Analysis of Law. Boston: Little Brown.

Rothbard, Murray. (1990). What Has Government Done to Our Money? Auburn, AL: Ludwig von Mises Institute.

Scott, James C. (1998). Seeing Like a State. New Haven: Yale University Press.

Scully, Gerald W. (1992). Constitutional Environments and Economic Growth. Princeton, NJ: Princeton University Press.

Selgin, George. (1994). "On Ensuring the Acceptability of a New Fiat Currency." Journal of Money, Credit and Banking 26: 808-826.

Selgin, George, and Lawrence White. (1994). "How Would the Invisible Hand Handle Money?" Journal of Economic Literature 32(4): 1718-1749.

Shleifer, Andrei, and Robert Vishny. (1998). The Grabbing Hand: Government Pathologies and Cures. Cambridge: Harvard University Press.

Streeten, Paul. (1995). Thinking About Development. New York: Cambridge University Press.

Volckart, Oliver, and Antje Mangels. (1999). "Are the Roots of the Modern Lex Mercatoria Really Medieval?" Southern Economic Journal 65(3): 427-450.

White, Lawrence. (1995). Free Banking in Britain: Theory, Experience and Debate 1800-1845. London: Institute of Economic Affairs. 